\title{
The third-party Logistics Application in the automotive Manufacturing Enterprises
}

\author{
Yin Hang \\ Engineering Training Center \\ Shenyang Aerospace University \\ Shenyang, China \\ Yinhang@sau.edu.cn
}

\begin{abstract}
Competition among domestic automotive market has become increasingly fierce because of the globalization of Chinese automotive market as well as participation and investment of overseas automotive giants. As professional logistics enterprise, the third-party logistics possesses professional logistics talents and experience as well as modern logistics system and broad information platform for logistics, which can improve an enterprise's core competition and service quality while lowering the logistics cost. Meanwhile, it can make quick reaction to market demands by timely track and information service so as to reduce the logistics risk of an enterprise.
\end{abstract}

Keywords-the third-party logistics, automotive manufacturing enterprises, operation mode of third-party logistics

\section{INTRODUCTION}

Among all the logistics, automotive logistics is considered to be the most complicated and professional logistics. The automotive logistics has four modules, including supply logistics, production logistics, sales logistics and recycling logistics, within which the transportation and distribution of supply logistics for auto parts in our country can't meet the need of modern market competition in automotive industry. While third-party logistics is an effective method and strategy for realizing the integration of logistics supply chain by offering an integrated mode to make chain supply of small quantities more economical. At the same time, by outsourcing, automotive manufacturing enterprises can input their limited resources to core business with dropping off burdens of manpower and financial resources. Besides, as professional logistics enterprise, the third-party logistics possesses professional logistics talents and experience as well as modern logistics system and broad information platform for logistics, which can improve an enterprise's core competition and service quality while lowering the logistics cost. Meanwhile, it can make quick reaction to market demands by timely track and information service so as to reduce the logistics risk of an enterprise.

\section{MAIN FEATURES OF THIRD-PARTY LOGISTICS IN AUTOMOTIVE MANUFACTURING INDUSTRY}

\section{A. Established on the basis of modern electric information technology}

Development of information technology is the necessary condition for the emergence of third-party logistics. With the fast and accurate transmission of data by information technology, management of warehouse, loading and unloading transportation as well as purchase, order, delivery and automatic order processing have all been improved, which realizes the integration of order, package, storage, transportation, flow and processing. Communication and cooperation among automotive manufacturing raw material supplier, automotive manufacture and sales enterprise can be better conducted due to information technology so that the coordination and cooperation among them can be finished in a short time.

\section{B. Individualized logistics service}

Apart from public logistics service, third-party logistics service in automotive manufacturing industry has few service objects, usually only one or several, but with a long time which can last for several years since the business process on demand side is different while logistics and information flowing with value stream. Therefore, the third-party logistics service should be specifically formulated according to customer's business process, which makes the automotive manufacturing industry special with characteristic.

\section{Integrated interests and risks due to alliance relationship}

1) The third-party logistics has a strategic cooperative relationship with automotive manufacturing enterprise instead of traditional trading relationship.

The third-party logistics is not simply a forwarder or express-delivery company, instead it is strategic ally of automotive manufacturing enterprise. In terms of service content, it provides automotive manufacturing business with a long-term contractual and comprehensive logistics service rather than one-time transportation or delivery service, which can guarantee the efficient operation of logistics system and constant optimized management of supply chain for automotive manufacturing enterprises.

2) Integrated interest is the profit basis of third-party logistics

Essentially profit of third-party logistics comes from the new value of scientific promotion under modern logistics management, which is usually called "the third source of profit". Saving of storage cost is the new value created by scientific logistics and this new value is share together by third-party logistics business and automotive manufacturing enterprise, which is integration interest. Therefore, the interest of third-party logistics is consistent 
with automotive manufacturing enterprise's, which is fundamentally different from the traditional operation.

3) The third-party logistics business is also the risk bearer

What third-party logistics business pursues is not shortterm economic benefits, rather more precisely, it serves the automotive manufacturing business as an investor. As for this long-term investment, benefits for third-party logistics business actually depend on increase of business in automotive manufacturing enterprise. Therefore, due to the interdependent relationship, third-party logistics business will bear some risks while gaining profits.

\section{CURRENT APPLICATION AND DEVELOPMENT OF THIRD-PARTY LOGISTICS IN AUTOMOTIVE MANUFACTURING ENTERPRISES}

\section{A. Status analysis of third-party logistics in automotive manufacturing enterprises}

Generally, as for all the domestic automotive manufacturing enterprises, they have gradually replaced their self-logistics by cooperating with third-party logistics in face of fierce competition. Application of third-party logistics mainly includes the following modes.

1) Group mode of comprehensive logistics by joint venture

Comprehensive logistics group is established together by automotive manufacturing enterprise and professional logistics company to charge the logistics business in manufacturing business by providing timely transportation of raw materials (JIT), product agent, logistics design and so on. Also it can help to pick and deliver goods for distributors and customers totally.

2) Establishing operation mode of strategic alliance

The automotive enterprise forms a strategic alliance with logistics business by contract to share information, technology and business ability. For example, Beijing Hyundai automotive co, ltd established a strategic alliance with Jilin Changjiu logistics co, ltd, and then transit business of Beijing Hyundai has been charged by Changjiu logistics.

\section{3) Outsourcing mode of partial logistics business}

The automotive manufacturing enterprise outsources partial logistics business to professional logistics company by contract with the logistics process and scheme designed by automotive manufacturing enterprise. As for automotive business, outsourcing mode can promote the specialty of logistics business with less investment and simple management but better result. Specially the automotive enterprise can choose new logistics supplier again when their business volume and product variety changed. So some enterprises with weak strength adopt this mode universally.

The delivery function of logistics has to be separated from manufacturing enterprise under the background of an increasingly deep and detailed social division of labors. Therefore, it is the development trend of world automotive logistics to entrust partial functions of logistics management to third-party logistics system to reduce operation cost and investment so that the enterprise can concentrate its resources on core business to improve the development of new product as well the products' quality. The third-party logistics mode will become the lead logistics in the future.

\section{ANALYSIS, PROBLEMS AS WELL AS SUGGESTIONS OF THIRD-PARTY LOGISTICS CONDUCTED BY AUTOMOTIVE MANUFACTURING ENTERPRISES}

\section{A. Analysis of necessity}

The third-party logistics has brought many benefits for enterprises since they can concentrate their attention on their main business for an optimal allocation of resources so that they can use the limited manpower and finance to compete with others by developing new products and basic technology. Meanwhile they can save cost, reduce capital backlog and stock so as to improve corporation image. Based on the advantages of third-party logistics, necessities for automotive manufacturers to develop it are as follows.

Automotive manufacturing enterprises can receive more professional services and reduce their operation cost, which can make third-party logistics more experienced and professional in organizing logistics activities for enterprises in return so as to reduce operational cost, improve service quality and enterprise's flexibility. Thus automotive enterprises can pay more attention to developing their core business.

Automotive manufacturing enterprises can concentrate on their core business. By outsourcing logistics, automotive manufacturers can build and promote their core ability by centralizing the limited resources so as to establish the entry barriers of this enterprise. Thus the entrusted enterprise can gain high profits for a long term and it can lead the whole industry to develop for its interest.

The monitoring cost of automotive manufacturing enterprises has been reduced with high efficiency. Actually logistics outsourcing reduces the scale to some extent so that the monitoring cost they need for self-logistics before has been reduced, and meanwhile production and operation efficiency can be improved with professional logistics.

Operational risk can be reduced in automotive enterprises. By outsourcing logistics, automotive enterprises can establish strategic alliance with other relative enterprises to reduce the time from development, design, production to sales with the advantage of strategic cooperation. Thus product risk due to the change of technology and market demands in a long time can be reduced.

Customer service level can be elevated for automotive manufacturing enterprises 


\begin{tabular}{|c|c|c|c|}
\hline Functions of logistics & Classifications & Contents & $\begin{array}{l}\text { Status quo of third- } \\
\text { party logistics }\end{array}$ \\
\hline Transportation & - & long distance, linear & Basically equipped \\
\hline Delivery & - & short distance, plan & Basically equipped \\
\hline Storage & $\begin{array}{l}\text { Preserve } \\
\text { store }\end{array}$ & $\begin{array}{ccc}\text { preserve } & \text { for } & \text { long } \\
\text { time, storage } & & \\
\text { preserve } & \text { for } & \text { short } \\
\text { time, flow } & & \\
\end{array}$ & Basically equipped \\
\hline $\begin{array}{l}\text { Distribution and } \\
\text { processing }\end{array}$ & $\begin{array}{l}\text { Processing } \\
\text { Production }\end{array}$ & $\begin{array}{l}\text { commercial } \\
\text { inspection, pick, place, } \\
\text { prepare goods, allocate } \\
\text { assemble, select, cut } \\
\text { off, standardize }\end{array}$ & Shortage \\
\hline Package & $\begin{array}{l}\text { Industrial package } \\
\text { Commercial package }\end{array}$ & $\begin{array}{l}\text { Transport, save and } \\
\text { package, internal and } \\
\text { external package } \\
\text { Sales package, } \\
\text { special package }\end{array}$ & Shortage \\
\hline $\begin{array}{l}\text { Loading } \\
\text { unloading }\end{array}$ & $\begin{array}{l}\text { Load } \\
\text { Unload }\end{array}$ & $\begin{array}{l}\text { activities } \\
\text { logistics facilities to } \\
\text { traffic authorities } \\
\text { activities from traffic } \\
\text { means to logistics } \\
\text { facilities }\end{array}$ & $\begin{array}{l}\text { Basically equipped, } \\
\text { but it cannot be } \\
\text { connected to other } \\
\text { logistics functions, } \\
\text { resulting in isolated } \\
\text { information }\end{array}$ \\
\hline Information & $\begin{array}{l}\text { Logistics information } \\
\text { Commercial } \\
\text { information }\end{array}$ & \begin{tabular}{lr}
\multicolumn{2}{c}{ Quantity } \\
management, operation, \\
track of $\begin{array}{r}\text { goods, } \\
\text { management }\end{array}$ \\
warehouse; \\
management; \\
management: & operation \\
automatic \\
selection, r digital \\
preparation and delivery: \\
POS, EOS, VAN, EDI; \\
finance: bank, network \\
insurance payments
\end{tabular} & Basically equipped \\
\hline Resolutions & & $\begin{array}{l}\text { Ability to control the } \\
\text { supply chain, } \\
\text { collaborative ability of } \\
\text { supply chain, plan and } \\
\text { design of logistics } \\
\text { network }\end{array}$ & Shortage \\
\hline
\end{tabular}

Figure 1. Status quo of domestic third-party logistics

Corporation image of automotive enterprises can be promoted. The third-party logistics enterprise formulates tailored logistics scheme with low cost but high efficiency oriented by customers, which creates favorable conditions for customer enterprises to make them stand out the competition.

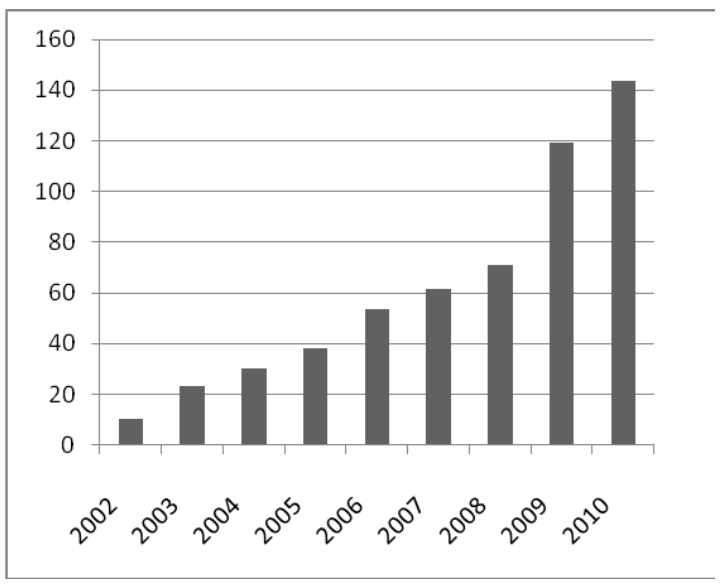


Figure 2. Auto production in Shenyang from 2002 to 2010

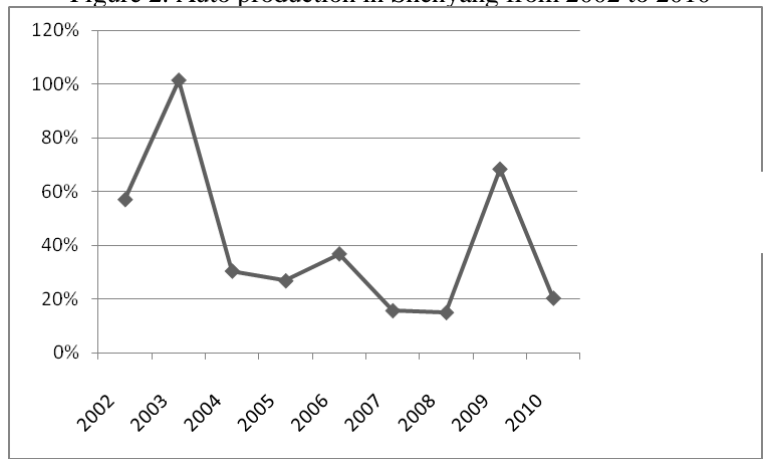

Figure 3. Annual growth rate of auto production in Shenyang from 2002 to 2010

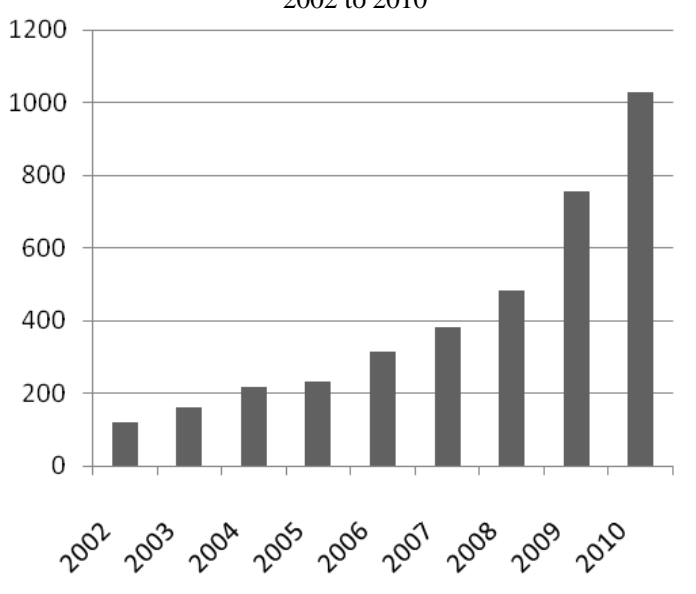

Figure 4. Auto output value of automotive in Shenyang from 2002 to

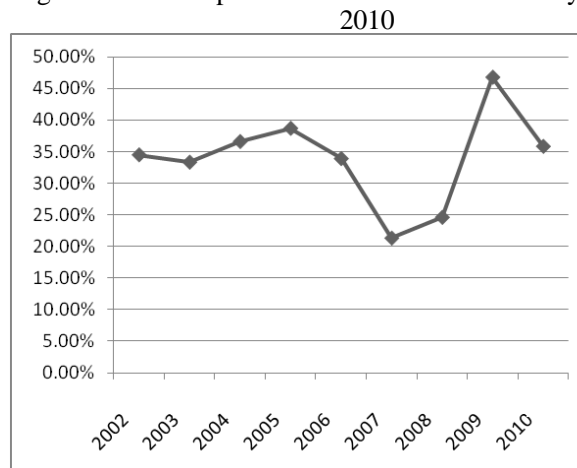

Figure 5. Annual growth rate of auto output value in Shenyang from 2002 to 2010

\section{B. Existing problems}
1) Conceptual obstacle
2) Technological obstacle
3) Legal obstacle

\section{Countermeasures}

1) automotive manufacturers should fully recognize the good logistics service brought by third-party logistics by changing their former concept to third-party logistics idea.

2) Improving technology and service level

3) Supported by macro policies

4) Choosing third-party logistics correctly

\section{PROSPECT AND DEVELOPMENT TREND OF THIRD- PARTY LOGISTICS CARRIED OUT BY AUTOMOTIVE ENTERPRISES}

The world automotive manufacturers pay great attention to logistics management with reducing the cost and broadening profit space as possible as they can. In American and European countries, automotive logistics in over $80 \%$ automotive enterprises have been outsourced to third-party logistics companies, which is also useful and beneficial for China automotive industry under high-speed development.

The future trend of automotive industry is to strengthen the industry division. Production of accessories and logistics delivery will be separated from manufacturing enterprises with entrusting partial functions of logistics management to third-party logistics so as to reduce the operational cost and investment so that they can concentrate resources on core business to improve the development of new product as well as product quality. Therefore, the third-party logistics mode will become the leading logistics form in the future, that is, automotive manufacturers entrust partial or main logistics business to external third-party logistics company.

As for the professional third-party automotive logistics enterprises, they possess professional operational experience and technology of logistics, professional logistics network and facilities, as well as professional talents for logistics operation and management and modern logistics information system, which are beneficial for promoting the overall logistics efficiency in automotive industry. Specifically, its functions are as follows. First, on one hand, input of human resources, financial and material resources can be greatly reduced by introducing third-party logistics; and on the other hand, based on the advantage of advanced logistics concept and strong network, third-party logistics can allocate return cargo for commercial vehicles so as to raise the utility rate of commercial vehicles as well as save the time and cost. Besides, by refining division and outsourcing business, enterprise can have more energy to develop its core business so as to form its own core competitiveness. In addition, enterprise can have timely information communication with each section of all RDC with the efficient network information platform to receive fast feedback from the market so as to provide accurate market sales information for automotive manufacturers. Moreover, enterprises can disperse risks from government, economy, market and finance by allocating external resources because enterprises can be more flexible and adaptable to external environment by allocating external resources and sharing risks with third-party logistics business for its limited resources.

\section{CONCLUSION}

In China, with the fast development of automotive manufacture, there is stronger and stronger demand for third-party operational mode. All these modes can greatly reduce enterprises' logistics cost and improve their core competitiveness, including comprehensive group mode of logistics by joint venture, operational mode by establishing strategic alliance, or outsourcing mode of partial logistics business.

Starting from the basic concept of third-party logistics and automotive logistics, the paper believes third-party 
must be an effective way and the only trend to pull the development of automotive manufacture if the automotive manufacturers want to stand out in the fierce domestic and international competitions by analyzing the application trend of third-party logistics in automotive manufacturing industry home and abroad. Next, in order to approve this point, the paper gives analysis and verification on the necessities of third-party logistics conducted by automotive manufacturing enterprises. Every coin has two sides, there are also problems existing in automotive manufacture to have third-party logistics. For example, there will be weaker control for logistics by automotive enterprises, risk of disclosing customer information and higher conversion cost. And then some countermeasures are given addressing these problems. Finally according to my internship experience in Shenyang Aerospace Mitsubishi Motors Engine Manufacturing Co, Ltd, I found some actual problems in third-party logistics and gave some countermeasures through the intimate contact with the advantages and disadvantages of third-party operational mode in automotive manufacture.

According to this paper, in order to develop third-party logistics in automotive manufacture, two aspects should be valued. On one hand, the third-party logistics self should attach great importance to developing third-party logistics in automotive manufacturing industry and strengthening the cultivation and education of management talents; meanwhile the overall quality management of third-party logistics enterprises should be perfected and the third-party logistics district facing automotive manufacture should be collectively planned. On the other hand, more strategic cooperation between automotive manufacturers and thirdparty logistics enterprises should be strengthened to establish strategic alliance between them; besides they should form a strategic idea of win-win cooperation to confront fierce market competition; also auto manufacturers and third-party logistics enterprises should support each other to establish win-win strategic alliance; what's more, they should establish platform mechanism for information communication, information platform organization and standard system for logistics information.

\section{REFERENCES}

[1] Yang Zhengchun, The Research of ANJI-TNT Automotive Logistics Solution [D] Shanghai, Shanghai Maritime University, Dec, 2012.

[2] Zhao Yinxiang, Third-party Logistics_ the Best Choice for automotive Manufacture[J].Inner Mongolia Science, Technology and Economy, the 23rd issue:2-6. 2014.

[3] Ye Minghai, Gu Mingyi, Research on Third-party Logistics of Domestic automotive Manufacture[J]. Automotive Engineering, the 5th issue : 522-525. 2013

[4] Yanjun, Research on the Third-party Logistics of Automotive Manufacture under the Management of Supply Chain in Our Country[D]. Jiangxi : International Economic and Trade School in Jiangxi University of Finance, Oct, 2010.

[5] Qiting, Chen Haijing, Zheng Yingjia. Application and Effect of Third-party Logistics in Automotive Industry in Our Country[J]. Consumer Guide•Economic Study, the 7th issue, 2012.

[6] Zhao Changdong, Chenhao. Research on the Logistics Mode of Automotive Manufacture in Our Country[J].Traffic Standardization, the 5th issue, 2012:144-146.

[7] Yao Zuoping. Comparison and Selection of Logistics Mode for Automotive Manufacturers in Our Country[J].Technological Entrepreneurship Monthly, the 9th issue, 2013 : 81-82.

[8] Xu Yaowen, Evaluation and Research on the Logistics Mode and Operational Effect in Automotive Manufacturing Enterprises[D].Harbin:Managerial Science and Engineering in Harbin University of Science and Technology,Mar, 2011.

[9] Zhang Lanfang, Zhangying.Evaluation and Selection by ThirdLogistics Service Supplier in Automotive Manufacturing Industry[J].Management and Scientific Technology in SMEs (the first-period journal.the 9th issue, 2012:25-27.

[10] Zhang Lanfang.How to Choose Third-party Logistics Service Providers for Automotive Manufacture [J]. Automotive Industrial Study, the 10th issue, 2013:30-33.

[11] Cuiying, Wang Meiying.The Application Mode of Third-party Logistics in Automotive Manufacturing Industry[J].Market Modernization, the 2nd issue, $2010: 113-114$

[12] Yang Chunmei, Evaluation and Study on Third-party Logistics Supplier for Automotive Manufacturing Enterprises[D] Dalian : Enterprise Management in Dalian University of Technology, Dec,2013.

[13] Zhaoyan, Research on the Selection of Logistics Operational Mode in Automotive Manufacturing Enterprises[D] Dalian : Logistics Engineering in Dalian Maritime University, Dec, 2012.

[14] Liu Xiaofang, Research on the Third-party Logistics Facing Liuzhou Automotive Manufacture[D] Guangxi : Enterprise Management in Guangxi Institute of Technology, May, 2012.

[15] Zhang Yongxia, Discussion on the Main Features of Third-party Logistics in Automotive Manufacturing Industry[J]. Study on Automotive Industry.Jan, 2013. 